\title{
マシンビジョン技術の実利用
}

\author{
非会員 鷲見 和彦* 正 員 金子 俊一**
}

\section{Real Application of Machine Vision Technology}

Kazuhiko Sumi, Non־member, Shun'ichi Kaneko, Member

キーワード：画像処理, 画像認識, オートメーション, ロボットビジョン, ヒューマンインタフェイス, セキュリティ, ITS

Keywords : image processing, image recognition, auto mation, robot vision, human interface, security, ITS

\section{1. マシンビジョン技術とは}

マシンビジョンとは，画像を撮影するイメージングデバ イスと，それによって撮影された画像を処理するプロセッ サとを持ち，システムを制御する処理結果を出力する視覚 装置を意味する。これと近い技術分野としてコンピュータ ビジョンとロボットビジョンがあるが，前者においては認 識すべき対象を記述・理解するための機能解析や手法開発 が主な目的であり, 必ずしも出力を制御に用いるとは限ら ない。また, 後者は制御対象がロボットに限定されており, 対象とするロボットの目的や機能に関連してセンシングや 画像認識機能を捉えている。一方, マシンビジョンではよ り広い意味の自動制御システムのための視覚機能全般を指 しており，照明光や対象物の姿勢制御などの撮像環境制御 をも合わせて考慮しながら設計を進める必要が特徵的であ る。一方, マシンビジョンと呼ばれる光学機器・カメラ・ 画像処理装置の市場が形成されており, これらは主に半導 体・電子機器などファクトリーオートメーションを中心に, 食品や医療などの評価・分析の自動化をサポートするもの である。

本解説では，マシンビジョンの実利用分野として，2. 章 では黎明期からファクトリーオートメーションと産業用ロ ボットの実用化まで, 3. 章ではヒューマンインタフェイス, 4. 章では ITS, 5. 章でセキュリティをとりあげ, その応用 事例と, 技術の主要なトレンドを紹介し現在の課題を議論 する。6. 章では共通した技術課題を概観し，特に実環境で の信頼性を向上させるロバスト画像処理を取り上げ, 最後 に今後の展開を予測する。

* 京都大学大学院情報学研究科知能情報システム専攻 于606-8501 京都市左京区吉田本町

Department of Informatics, Graduate School of Kyoto University Yoshida Hon-machi, Sakyo, Kyoto 606-8501

** 北海道大学大学院工学研究科システム情報工学専攻 T060-0808 札幌市北区北 13 西 8

Division of Systems and Information, Graduate School of

Hokkaido University

Kita-ku, Sapporo 060-0808

\section{2. オートメーションとロボットへの応用}

〈2·1〉 マシンビジョンの黎明期マシンビジョン(以 下ビジョンと略す)という言葉が定着する前に, コンピュー タによる画像処理を機械制御に始めて応用したのは, OCR とファクトリーオートメーションの分野である。国内では, 1970 年代に実施された通産省の大型プロジェクト「パター ン認識」による技術牽引の効果が大きく, カメラやスキャ ナで読み取られた画像を二值化し, 文字や物体のシルエッ 卜を認識する技術が育成された。OCR は郵便番号読取装置 などに応用された。ほぼ同時期に, 組み立てロボットの制 御を対象としたビジョンの研究が行われた(1)(2)(6)。しかし, スキャナで読み取られる二次元のパターンにくらべ， 3 次 元的な形状を持つ部品の位置姿勢認識は画像認識の複雑度 が高いため, 画像処理の時間がかかり, また, ロボットの 手先も器用ではなかったため, 実現できる作業のレベルが 低く，普及することはなかった。

〈2·2〉 オートメーションにおける位置決め応用 そ れに続く 1980 年代初期にかけては, とくに, 半導体製造装 置の分野で実利用が進んだ。半導体生産では作業対象が小 さく, サブミリ精度の精密な位置合わせが必要で, かつ, メカニカルな位置決めが困難である。その上, 生産量が膨 大であるという特徴をもっており, ビジョンによる自動化 がなければ，顕微鏡作業を人手で行わねばならないという 状況であった。このような強いニーズに加え, 半導体は薄 いウエハ形状をしているために画像パターンが 2 次元的で あり, 扱いやすいという特徴もあったため, 応用事例が多 く見られる。アルゴリズムとしては, 初期には 2 值画像(3) や1 次元に投影した投影パターンのマッチングが用いられ たが, 現在では 2 次元濃淡パターンを直接比較するイメー ジマッチング(5)が主流である (図 1 参照)。

つづいて, ビデオデッキなどの精密電子機器組み立てや プリント基板の製造にビジョンが応用された。これらの電 子機器では, 組み立て時の部品取り付け方向が, 基準平面 へ垂直方向からの取り付ける設計が可能であり, 半導体で 
培ったビジョン技術を応用することが出来た。ただし，部 品の形状が複雑で, 回転方向の自由度が大きく, また 3 次 元的な陰影を持つ場合や, 照明との相互作用で見え方が変 わるなど，半導体にはない困難さの克服が求められた。そ のため，陰影のつきにくい照明系や，回転に依存しない穴・ 面積・寸法を用いた認識対象のモデリングなどが発達した が，現在では，回転を考慮したイメージマッチング，エッ ジや特徵点の位置関係をモデル化する一般化 Hough 変換, 形状特徴の組み合わせを投票するジオメトリックハッシン グおよびその拡張を用いることが多い(21)。

さらに，図 1 下段のように三次元的な対象を多方向から 見た場合の多様な見え方を効率よく表現する固有空間（部 分空間）法，固有空間と物体姿勢との関係を記述するパラ メトリック固有空間法(17)や図 2 に示すように 3 次元形状を 直接計測してロボットを制御する 3 次元ビジョンシステム (22)(15) も実用化された。一方, 個別の物体に対する認識結果 の誤りを全体の整合性を基準に修正する(20)ことも有用であ る。

また，床に張ったテープやマークを読み取り走行を制御

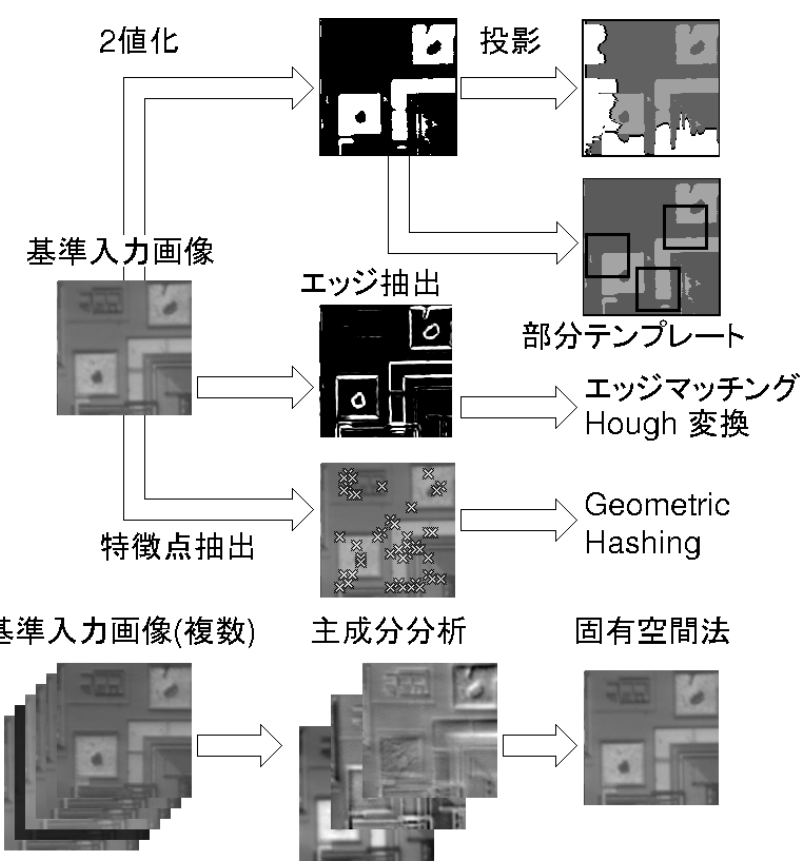

図 1 位置合わせに用いられる画像特徵の例

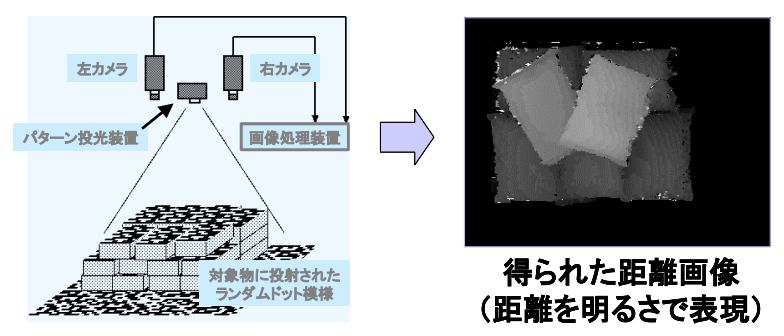

図 2 ランダムドット投光により 3 次元形状を直接計測する ロボット用ステレオビジョン
する自律搬送ロボットも実用化された。従来の電磁誘導方 式に比べ搬送経路を変更しやすいことや半導体工場特有の グレーティング床上にも設置できることが喜ばれた。研究 レベルでは, 部屋や廊下の形状や目標地点での特徴的な景 色を自動学習するランドマーク認識やマップ生成も試みら れているが，コストと信頼性を要求されるオートメーショ ンの現場ではまだ普及していない。

$\langle 2 \cdot 3\rangle$ 外観検査への応用組み立て自動化へのビジ ヨン応用が進み, 自動化率が高まるにつれ，検査工程に人 が集中するようになってきた。そのため, 検査工程のコス 卜削減や検査基準の安定化が重要課題となり, ビジョンに よる自動検査，とくに外観検査のニーズが高まってきた。 1980 年代初期から，まず，取り組まれたのは IC やプリン 卜基板のパターン検查, 印刷物の印刷品質の検査, 鉄鋼ラ インにおける鋼板の傷や形状の検査 ${ }^{(11)}$, および，ガラス瓶 の傷や異物混入検査などである。これらの生産ラインは, 極めて高い検查速度と精度が求められる上に, 微細であっ たり, 高速で移動していたり, 高温であるなど人手による 検査・計測が極めて困難であるため, 自動化への要求が極 めて高かった。そのため, レーザや光ファイバを駆使した 専用の光学系・撮像系・ハードワイヤードロジックを駆使 した処理系が特別に開発された。

配線パターンの検査(4)(10)では，まず，パターンの設計ル 一ルを用いたルール法が考案されプリント基板に適用され た。また長尺の印刷物も同様の方式で検査されることが多 い。また, 本来同じ形状であるはずの二つのパターンを相 互比較する二対比較法は IC などのように同一形状が繰り返 し存在する検查対象に用いられ, 局所的に発生するごみの 付着によるパターン異常の検査に力を発揮した(13)。また, CAD データと実物とを比較する手法(14)も現れた。

大面積の検査対象から微小な傷や異物を発見する方法と しては, レーザを斜め方向から照射して傷や異物からの散 乱光を検出する方式や, 対象の像を $\mathrm{f}-\theta$ レンズを通してフー リエ変換し, 周波数領域において良品から作成されたフィ ルタをかけて, 異常パターンだけを強調する光学的フーリ 工変換方式(25)など, ビジョンの入力部において光学的な信 号増強を行う手法が主に採用されている。また, 微小な凹 凸などを検査する手法としては, 光干渉計測(27)を応用する ことも多い。

このような微細大面積のパターン検査に続いて, 外観検 查の中でも, 平面上の 2 次元パターンを判別するような検 查, たとえば，印刷マーク・コード・文字の読み取りによ る正誤判定, それらの印刷品質の検査, 2 次元的なパター ンの面積や長さの測定は, 撮像条件や照明条件の安定化と いう課題を解決すれば, パターンとしては比較的単純であ り，1980年代後期から実用化が進んだ(7)(54)。

一方, 検査の中でも対象が 3 次元的であり, 視点位置や 照明条件によって見掛けが大きく変わるものや, 計測項目 そのものが 3 次元形状に関するものについては, ニーズは 高いものの, 難しい技術課題が多く実用化が遅れた。初期 
の実用化事例には，照明を工夫することにより，対象の 3 次元形状を影や輝点などの 2 次元パターンとして抽出して, 2 次元パターン認識の技術を適用することが行われた。これ らの技術は IC のリード曲がり検査や樹脂モールド部品の欠 けの検査 ${ }^{(8)(9)}$ に用いられている。

このように照明に大きく依存した検出・撮像系は，検査 対象の形状が大きく変わる度に, 撮像部分の作り直しや調 整に手間がかかり，1990 年代に入って生産のサイクルが短 縮化し多品種生産が一般化すると, 検査対象の形状をより 直接的に計測する方法へと進化した。たとえば，プリント 基板のはんだ付けの検査では，図 3 に示すように最初は位 置と広がりを精密に調整された照明を照射し, その反射か らハイライトパターンを抽出し, 八イライト部の形状から はんだ付けの良否を判定する手法が多く見られたが，光源 を多色化してカラーカメラで撮影することにより，どの方 向の光源からを一番強く反射するかを判断し, 表面の法線 方向の分布を大まかに取得する手法が提案されている。ま た, IC のワイヤボンディング検査では, 実体顕微鏡の光学 系を用いてワイヤの形状をステレオ計測したり(26)，3 次元 的な合焦位置を辿ることでワイヤの形状を検査したりする 手法が実用化された。さらに, 精密な 3 次元形状計測法と して走查型レーザの反射光(16)や共焦点光学系(18)を用いた 3 次元計測手法が IC フリップチップボンディングの接合部ボ ール形状検査検査装置に用いられた。

その他 3 次元形状の検査としては，シート状に照射した レーザ光の反射を見る光切断法を, 検査対象の移動を併用 して用いる溶接ビード形状検査・鋳物の形状検査に応用し た事例(19)や格子縞を照射しその位相変異を計測する電子モ アレ法(27)によるパイプ形状検査などで実用化事例がある。

このようにオートメーションの世界では, 位置決めと検 查においてビジョンの活用が不可欠になっているが，それ でも人に頼らねばならない領域があった。それは，人の視 覚の感覚（或いは感性）に依存した領域で, たとえば，デ ィスプレイモニタの画質や外観による品質の選別などであ
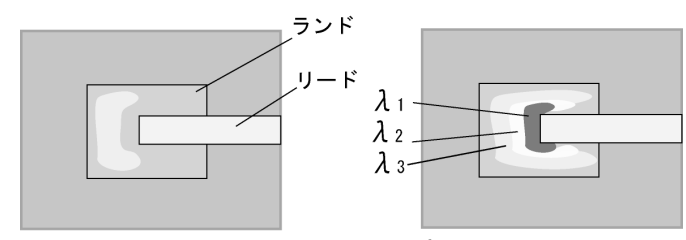

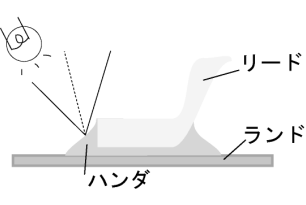

一光源による ハンダ付け形状の推定

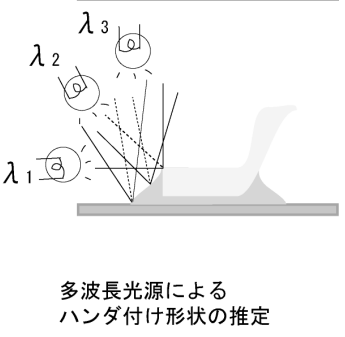

図 3 半田付け検查における多波長化による 3 次元形状の計測
る。このような領域は官能検查と呼ばれ，1990 年代に大き く進歩した。官能検査では二つの大きな技術課題が解決さ れた。ひとつは, 人の定性的な感覚をいかに計測可能な物 理量と相関付けるかという問題であり, 熟練者からの聞き 取り調查をもとに因子分析法で関連する計測項目を抽出す るなどの方法論が確立された(28)。もうひとつは, 人の微妙 な感覚を再現可能なマルチバンド光計測(56)やカラー画像処 理系である。

\section{3. ヒューマンインタフェイスと人の計測}

つぎに，ヒューマンマシンインタフェイスへのビジョン の応用について紹介する。画像処理を用いて, 人の位置・ 姿勢・動きを計測したいというニーズは研究開発現場から ロボットティーチングまで幅広く存在した。研究レベルで は非常に多くの発表が行われている(29)。多くは, 人の存在・ 位置・手足の姿勢・指先・顔の向きや視線方向などを画像 から抽出してインタラクティブな環境を作ろうというもの である。既存のキーボード・マウス・ジョイスティックな どのインタフェイスデバイスから開放された柔軟なインタ ラクションが期待できる。しかし，この分野で実用化され て生き残るには, ビジョン以外の計測手法や意思伝達法と 比べて, 簡単・確実・正確・安価に実現できなければなら ない。

そのなかでも, 眼球近くに設置した照明の角膜反射と睹 や瞳孔との位置計測を用いて眼球の向きを計測する視線検 出装置（図 4 左）や人体の主要な部位と関節にビジョンで 識別可能なマークを取り付けて, その位置を複数のカメラ で追跡することにより人体の位置姿勢を計測する装置 (図 4 右）(モーションキャプチャ)は製品化され, 研究や映像メデ イアにおける人体モデリングの用途に使用されている。ま た, 小さなものとしては, 光学マウスでは LED で照明され た机の表面を撮影し, 微細なテクスチャを投影した X/Y 方 向の 1 次元プロファイルのマッチングによって移動量を計 算している。さらに, 最近ではビデオゲームのインタフェ イスとしてカメラや画像センサを持つもの ${ }^{(57)}$ が製品化され ている。

操作者の顔検出や姿勢計測など，この分野における基本 的な検出技術は後に述べる個人識別の分野における技術と 共通性を持つものも多く, 今後両分野における需要を満た すために研究開発が要望されている。
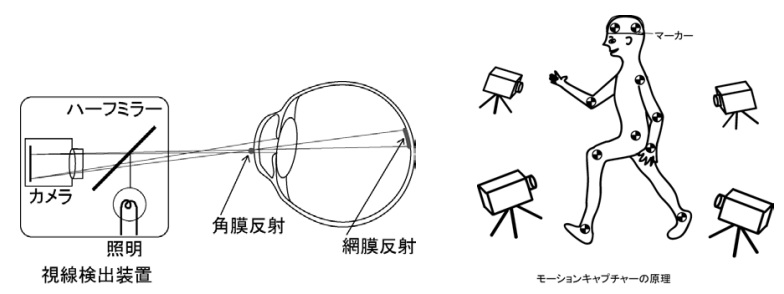

図 4 視線方向検出の原理と人体姿勢の検出原理 


\section{ITS と道路交通への応用}

一方，1990 年代後半に脚光を浴びた ITS においてもさま ざまなビジョン応用が提案された(30)(31)。ITS でのビジョン 応用には大きく分けて次のようなものがある。まず，車載 カメラから道路の車線境界や道路上の他車・歩行者・障害 物をみて速度・操舵を制御するもの（図 5)。つぎに，車載 カメラで運転手や車内を観察し，運転状況や乗員の状況を 見たり，意図を理解したりして車両を制御するもの。最後 に，道路に設置されて，通過する車両や道路環境を計測し， 道路管理者や運転者に情報を提供寸るものである（図 6）。

速度・操舵制御については, 1980 年代から自動走行の研 究が続けられ，主に，道路の白線を検出して走行車線を認 識する手法が確立された。前方や後側方の車両の認識はビ ジョンでも可能であるが，より，確実な電波レーダやレー ザレーダを用いるか併用することが多い(32)。ほとんどの方 式は単眼カメラを用い, エッジ検出によって得られた白線 を走行方向につなぎ合わせて車線としているが，障害物検 出や白線の検出をより確実なものにするため, ステレオビ ジョンを適用する事例も見られる。90 年代に入って実証実 験が進み，大半の道路で自動走行可能であることが検証さ れている(33)が，道路や環境の変動が大きく認識の絶対性を 保証することは困難であり，現在では車線逸脱/接近警報装 置としていくつかの車種に採用されているにとどまってい る。また, 運転手の居眠りや視線の検出も, ほぼ実用化さ れているが，コストとユーザメリットの点で標準装備され

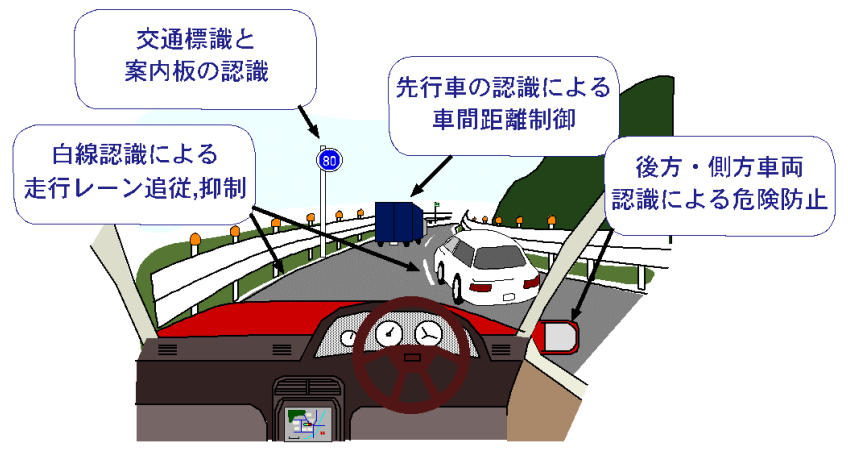

図 5 ITS 車載ビジョンシステムの役割の例

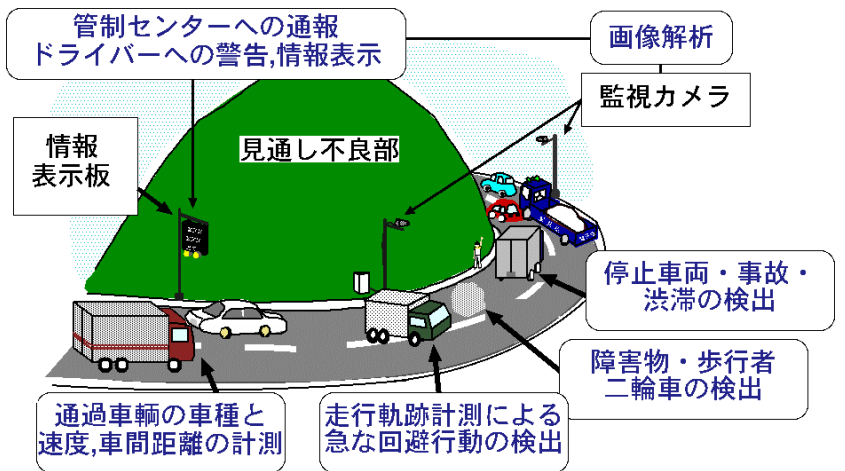

図 6 ITS 道路ビジョンシステムの役割の例 (衝突防止システム)
るにはいたっていない。

一方，道路側では，道路を見渡すように設置したカメラ により一台ごとの車両の車種と位置を計測して渋滞や停止 車両を検知し, その存在を後続車両に知らせる衝突防止装 置(34)，ほぼ直下を通過する車両の車種と速度だけを検知す る画像式トラフィックカウンター(35), 駐車場の空きを計測 する車両検知装置 ${ }^{(36)}$, また文字認識の応用として, 二箇所 で車両のナンバープレートを読み取り二地点間の時間をも とに旅程時間を後続車にしらせる旅程時間計測装置や覀一 卜通過時にナンバーを読み取って発券を行うためのナンバ 一読取装置(37)などが用いられている。道路環境計測のため には，道路に設置したターゲット前を横切る雪を観測する 画像式降雪検知装置や投光した光の道路上での反射や偏光 をもとに判断する凍結検知装置などが実用化されている。

屋外情景における安定な画像処理をめざすために，撮像 装置のダイナミックレンジの拡大技術が重要である。同一 視野を有する複数個の撮像板を用いて長短の露出時間設定 に対応する露出光量の異なる画像を用いて, 局所的な画像 判別により暗視野及び明視野の飽和画素を検出し適当な露 出量を選択する方式(38)が提案されている。対象物本来のテ クスチャの変動の問題などはあるものの普及が望まれている。

\section{5. 監視カメラとセキュリティへの応用}

〈5·1〉監視カメラとセキュリティへの応用オート メーションをはじめとした自動制御におけるビジョン応用 がほぼ一巡した現在, 画像処理の市場の関心はセキュリテ イや監視カメラの応用に向けられている。犯罪抑止効果や 人的・物的な管理体制の強化を目的として, 監視カメラを 導入する機会は増えているが，通常は有事に備えて全体を 録画するだけであり，常時観察・詳細観察することは困難 である。そのため，マシンビジョン技術を応用して，人の 発見・クローズアップ・追跡が出来れば，監視の即応性を 高め，録画内容の分析を容易にすることが出来る。

そこで，映像から人を発見しその位置を計測する装置(侵 入監視装置と呼ばれることが多いや，移動する人を追跡し ながらカメラのパン・チルト・ズームを制御する人物追跡 システム（図 7）が実用化されている。

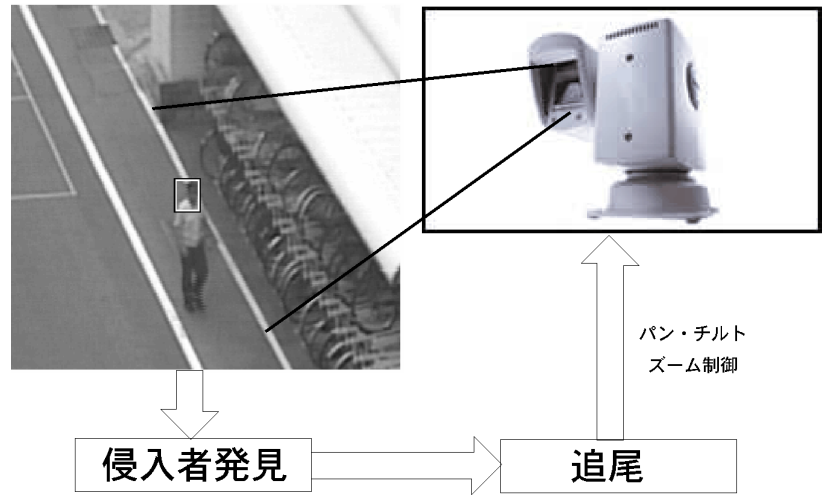

図 7 侵入者追跡型監視システム 
このような ITS や監視装置のビジョンに求められる特性 としては，照明や背景が制御されない環境において過剰な 検出（誤報）や検出漏れを少なくすることである。そのた め, 環境を観察することによって環境のモデルを自動的に 生成すること，(まだ出現したことのない）人や車などの認 識対象に関して, 過去の事例や一般的知識から対象モデル を生成しあらかじめ作りこんでおくことである。

背景については, 輝度や色の統計的な振る舞いをモデル 化し，それらを環境の変動に応じて逐次更新することが多 い。混合正規分布 ${ }^{(39)}$, 差分統計量(40)(53), ブロック間相関や パターン共起性(41)などがモデルとして用いられ, カラー画 像の統計量 ${ }^{(58)}$ を用いて影を除く試みも行われた。

対象については事前知識としてはシルエットの形状や運 動モデル(42)を用い, 発見後の個別対象のインスタンスとし て対象の見え方をテンプレートとして持つ事例(43)が多い。 また，移動経路をモデルパターンとして異常行動を検出す る手法(59)などマクロな特徵も用いられる。

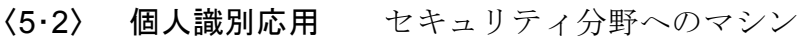
ビジョンのもうひとつの応用は個人識別である。現在ビジ ヨンを応用した個人識別(44)としては，図 8 に示すように指 紋(45) ・ 掌紋(46) ・ 掌形(47) ・静脈(48) ・ 網膜(49) ・ 虹彩(50) ・ 顔(51) ・ 耳殻(52)などがある。いずれの手法も取得した生体情報から 特徵量を抽出し, あらかじめ登録された特徵量との間で類 似度(もしくは距離)の計算を行う。

指紋や掌紋では，指や手とセンサとの光学的・電気的あ るいは機械的な接触度合いを定量化して二次元のパターン を得て, そこから指紋の隆線方向や分岐などの特徵点を抽 出する。掌形の場合には，指の長さなど特徵的な寸法をシ ルエットから計測する。静脈と網膜では血管パターンのマ ッチングを行う。静脈は赤外光で照明すると観測でき, 網 膜は瞳孔を通して網膜に結像する光学系を用いる。虹彩は 拡大した眼球像の瞳孔の回りに同心円状にパターンを走査
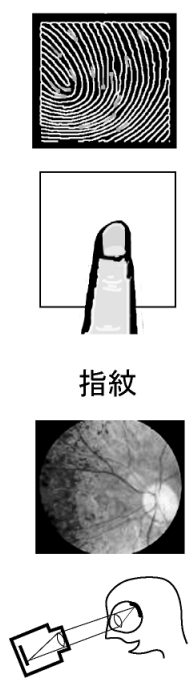

網膜
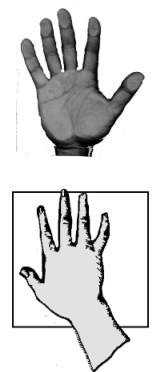

掌紋
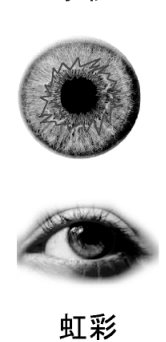
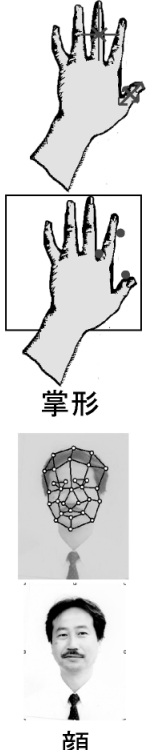

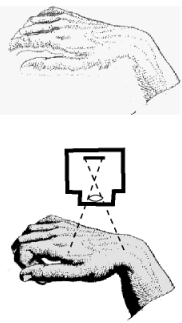

静脈

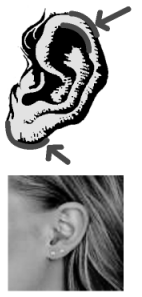

耳
図 8 ビジョンで計測可能な種々のバイオメトリクス
し得られた 1 次元パターンを周波数解析して特徴を求め る。顔の場合には, 特徵点ではなく眼と口の位置が重なる ように位置・倍率・歪みを正規化して二次元の画像パター ン同士のマッチングを行うことが多い。

現在実用実績の多いものは，指紋，掌形，虹彩であるが， 研究レベルでは顔(23)に対する期待が高い。これまで実用化 されている手法は, 指を計測装置に接触させたり, 眼を力 メラに近づけたりするなど, 被験者から積極的に認証を求 めることが必要なのに対して, 顔による個人認証では, そ の制約が緩やかであると期待されるからである。しかし， 制約が緩やかな分だけ環境と撮影条件の変動が大きく, 特 に照明環境と顔の向きの変動に対して改善が試みられてい る(24)が照合精度についてはまだまだ改善の余地がある。そ のため個別のアルゴリズムの欠点を補って運用する複合認 証(55)も現れた。

\section{6. 共通技術課題}

これまで実際に利用されるに至ったマシンビジョンを概 観した。当初, 文字とマークの認識や半導体のように平面 的で傾きの少ない対象の位置決めにしか適用できなかった ビジョンが，屋外情景の認識や官能検查の自動化まで適用 可能にした技術の発展を集約すると次のようになる。

1. 高速性・(時間的・装置間のばらつきの)安定性・検 査結果の定量的基準・結果の蓄積などの点で, すで に人の能力を超えた性能を発揮している

・アルゴリズムの高速化技術(イメージマッチン グにおける各種の高速化など）

・ 非 NTSC カメラ(プログレッシブスキャン・高 解像度・高速カメラ・ラインスキャンカメラな どの普及)と計算機ネットワークの進歩

2. 回転なし平面的な対象 ( 2 次元物体)から, 姿勢が多 様な立体的な対象 (3 次元物体)一適用が拡張された

・ 一般化ハフ変換・ジオメトリックハッシングな ど自由姿勢パターンサーチ

・構造化照明やステレオ視による 3 次元認識

・焦点(ボケ)ステレオなど微細 3 次元認識

3. 照明分布・カメラと対象物体の位置関係など撮像環 境に対する制約条件の緩和が実現した

- 二值画像処理から濃淡画像処理一の技術変化

・照明むら補正や照明むら非依存の特徴抽出

・固有空間など物体見え方(アピアランス)モデル

4. 制御不可能な屋外環境への適応がなされた

・統計的な画像処理と統計的背景モデル

・モモデル不適合の例外を処理するロバスト統計

・物体追跡や字空間特徵抽出などの動画像処理

5. 従来, 熟練者だけが判断できた外観検査や官能検査 の定量的表現が可能になりつつある

・因子分析など人の心理的感覚の定量化技術

・ カラースペクトルなど人の感覚を超えた計測 次節では，これらの技術の中で制御不可能な環境の中で， 
外乱に対する耐性を高めることができるロバスト処理に着 目して紹介する。

\section{〈6・1〉 ロバスト処理照明変動による局所的明度変} 化, 光沢表面上のハイライト (明度飽和), 遮蔽によるパタ ーンの損傷への対応，などモデル化や制御が困難な問題に 対して一括的に対処するためにロバスト（頑健）処理が提 案されてきた(60)。個別技術の詳しい解説はそれぞれの論文 資料に譲り，ここでは画像パターン照合の分野に注目して それらの得失を論ずる。ロバスト照合処理とは探索対象と する画像パターンの局所に発生する例外的な異常領域の影 響を極力排して安定に検出する機能であり，ロバスト統計 の枠組或いは考え方（M-推定, 最小 2 乗メディアン推定, 順序統計量など）(61)を導入することによって解決しようと するものである。ロバスト特性を得るためには，上記のよ うな不良条件によっても不変的に観測画像内に潜在的に残 存する特徵量（従来はエッジなどの強い特徵量を用いる場 合が多かった）を選択的に抽出し，それに基づく評価量を 統計的にモデル化する必要がある。その上で評価量の統計
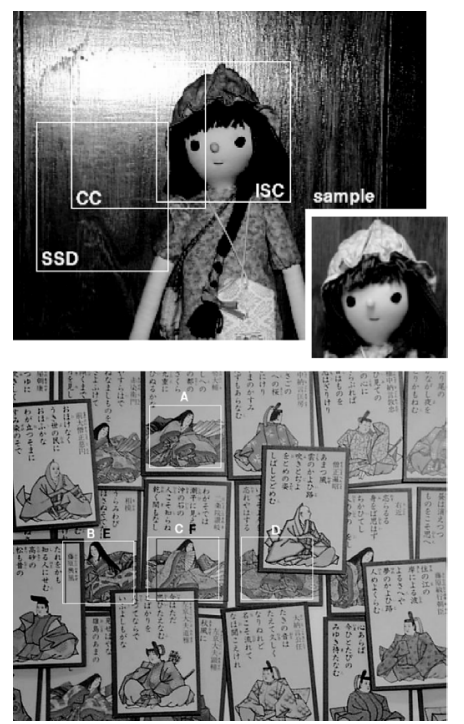

図 9 増分符号相関による画像照合

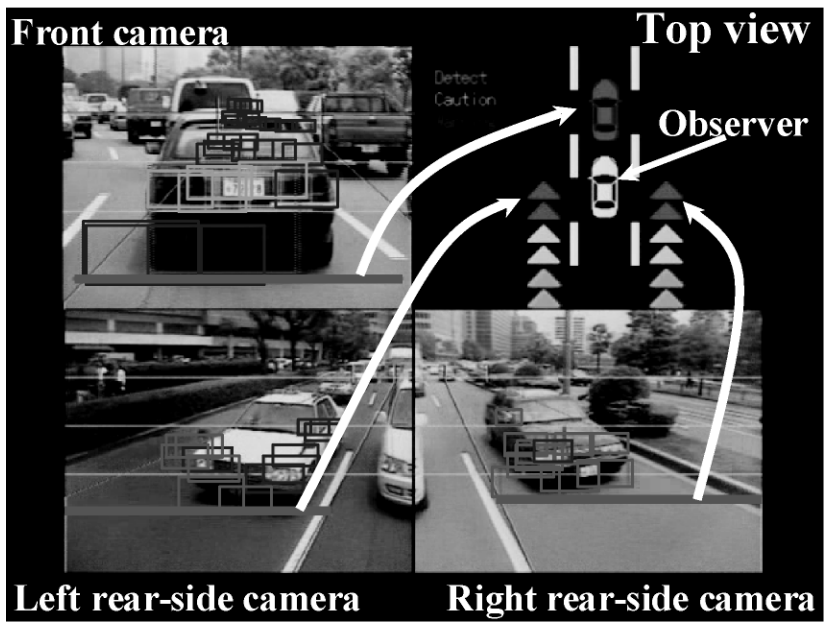

図 10 方向符号照合法による前方車両検出
的振る舞いの予測に基づいてしきい值などのパラメタを設 計する。

図 9 に示すような, 明度の増減傾向を二值符号不変特徵 量とする相関照合アルゴリズム(62)及びその顔画像に基づく 個人識別への応用(63), 明度の変化方向の分布に着目する照 合法(64)及びその前後方車間距離の推定法(65) (図 10 参照), 屋外情景におけるロバストな車両抽出を目的とした適応的 背景推定アルゴリズム(66)などが提案され実用をめざして検 討されてきた。これらの具体的アルゴリズムの設計におい ては，実システムにおける利用を想定した低コスト性（高 速・小規模処理）が重要となる。なお統計的パターン認識 の画像応用に関しては, 本特集のもう 1 編の解説をも参照 されたい。

\section{7. 今後の展望}

以上述べてきたように, 作業対象のモデルや作業の基準 が定量化しやすいオートメーション分野においては，マシ ンビジョンは人の能力を超えてその力を発揮する成熟期に 入っており，環境が制御しにくい事例においてもロバスト 処理の技術によって例外に対処できるようになった。一方， ここには触れなかったが多くの努力にもかかわらず試験的 に用いられただけで普及しなかった用途も存在する。

そこで，オートメーションの分野での成功事例を振り返 ると次のような特徴をもっていることがわかる。

1. 人に困難な作業の場合(顕微鏡・悪環境・超高速)

2. 視覚作業が画像情報によって定量的に記述できる場合

3. 画像上の見かけの変動が少ないか制御可能な場合

また，外観検査に関しては，単なる不良品の排除のため に用いるのではなく，検査結果の定量化とそれにかかわる 上流工程との因果関係を明らかにし, 不良率の低減・作業 効率の改善・作業者に依存しない品質安定化を達成するこ とで，マイナスをプラスに転じる発想が重要である。例え ば, 久陷画像の分類器の生成する結果から, 半導体製造プ ロセスの状態推定を行おうとする試み[坂田]などはその一 例である。

最近になって自動化が進み始めた官能検査や屋外情景を 対象とするセキュリティ・ITS の分野では, 環境の制御と対 象に対する事前知識の両方で上記の制約を満たしておら ず，前記の心理測定法や統計的な画像処理 - 動画像解析 • ロバスト処理を用いても，まだまだ挑戦的な分野である。 市場に定着するには今後も新しい技術の開発が求められる であろう。

(平成 15 年 9 月 1 日受付)

\section{文献}

（1）白井良明・井上博允：「ビジュアル・フィードバックを利用したロボッ 卜の組合せ作業」, 電総研彙報, 35, 3, pp.327-333 (1971-3)

(2) 㽦井芳昭・井上 驍：「視覚付ロボットによる物体の 3 次元位置方向 測定の一方法 $\rfloor$, 信学会論誌, 60-D, 8, pp.586-593 (1977-8) 
（3）依田晴夫・池田貞弘・江尻正員 :「回転形パターンマッチングによる形 状選別の試み」，計測自動制御学会論誌, 10, 3, p.284 (1974-3)

（4）河村貞和・中谷敏雄・目瀬道弘・烏野 武 :「傷検出のパターン認識と そのディスプレイについて」，通学会研資, IE73-33 (1973)

（5）鈴木悦四：「半導体製造におけるパターン認識技術」，ULSI，13，6, pp.33-36 (1985-6)

（6）深田陽司・土井 博・永峰啓二・稲荷隆彦:「山積みされた クランク シャフトの認識」，三菱電機技報, 59, 10, pp.30-33 (1985-10)

（7）舆水大和：「産業応用からみた画像処理アルゴリズムの動向」, 別冊 O plus E「画像処理技術の最新動向」, pp.172-187, 新技術コミニュケ ーションズ (1988)

（8）熟見和彦・辻堂仁規：「FA における画像処理技術の応用」，三菱電機 技報, 62,2 , pp.115-118 (1988-2)

（9）水野修児・木村和夫 : 「フラットパッケージ IC のリード検査技術の開 発」, 第 1 回インテリジェント FA シンポジウム, p.73 (1987)

（10）原 靖彦・中川 清:「局所的特徵の抽出と比較による回路パターンの 欠陥検出法」, 信学論誌, 66-D, 8, pp.970-976 (1983-8)

（11）長尾幸男：「鋼板用表面検査装置 - ホットストリップから冷延鋼板ま で」，テレビジョン学会技報, IPA58-4 (1982)

（12）広岡美和子・川戸慎二郎：「濃淡テンプレートマッチング法による基板 実装検査」，第 30 回自動制御連合講演会予稿集, p.559 (1987)

（13）橋本 学・熟見和彦・坂上義和・川戸慎二郎：「輪郭点情報を用いた高 速テンプレートマッチングアルゴリズム」, 信学論誌，J74-D-II，10, pp.1419-1427 (1991-10)

（14） 前田俊二・窪田仁志・牧 平坦 ・二宮隆典・中川泰夫・谷口雄三 : 「力 スケードパターンマッチングによるLSI ウェー八多層パターン自動外 観検査」，信学論誌, J72-D-II, 12, pp.2012-2022 (1989-12)

(15) R. Bolles, P. Horaud, and M. Hannah: 3DPO: "A Three- Dimensional Part Orientation System”, Int. J. of Robotics Research, Vol.5, No.3, pp.3-26 (1986)

（16）塚原博之・大島美隆・西山陽二・高橋文之・布施貴史：「バンプ検査の ための高速三次元計測技術」, 外観検査の自動化ワークショップ, pp.17-22 (1998)

（17） 村瀬 洋:「固有空間法による画像認識, in コンピュータビジョン技術 評論と将来展望」，新技術コミニュケーションズ, pp.206-217 (1998)

（18）石原満宏・佐々木博美 :「非走査マルチビーム型共焦点撮像系による高 速三次元計測」, 外見検査の自動化ワークショップ, pp.17-20 (1997)

（19）山本 新・小関 修:「光切断法を用いた部品形状の計測と検査」, 精 密工学誌, 56, 8, pp.1371-1374 (1990-8)

(20) M. Hashimoto, K. Sumi, and S. Kuroda : "Vision System for Depalletizing Robot using Genetic Labeling”, IEICE Trans. on Inf. and Syst., Vol. E78-D, No.12, pp.1552-1558 (1995)

（21）松山隆司・和田俊和：「Hough 変換：投票と多数決原理に基づく幾何 学的対象の検出と識別, in コンピュータビジョン技術評論と将来展 望」，新技術コミニュケーションズ, pp.149-165 (1998)

(22) 橋本 学・熟見和彦・羽下哲司・黒田伸一・小平紀生・岩田彰太郎:「ラ ンダムドットパターン投光ステレオを用いた物流ロボット視覚システ ムの開発」, 日本ロボット学誌, Vol.17, No.1, pp.48-49 (1999)

(23) 赤松 茂：「コンピュータによる顔の認識」, 信学論, J80A, 8 pp.1215-1230 (1997-8)

（24）福井・山口・鈴木・前田：「制約相互部分空間法を用いた環境変動にロ バストな顔画像認識」，信学論, J82D2, 4, pp.613-620 (1999-4)

(25) K. Kitagawa and M. Hayashi : "New Particle Counter Using Spatial Filtering Technique", Display Manufacturing Technology Conference, at San Jose, 105/108 (1999)

(26) S. Kawato and K. Sumi : "3-D Loop-shape Extraction of IC Bonding Wires using Binocular Stereo Technique", Proc. 1st Korea-Japan Joint Conf. on Comp. Vis., pp.234-239 (1991)

（27）山田朝治・横関俊介：モアレ縞・干渉縞応用計測法，コロナ社（1996）

（28）長田典子:「色感性における物理的パラメータと感性的パラメータの対 応付け」, 日本シミュレーション\&ゲーミング学会 2002 年度秋季全国 大会発表論文集, pp. 46-51 (2002)

(29) T. Moeslund and E. Granum : "A Survey of Computer Vision-Based Human Motion Capture”, CVIU, Vol.81, No.3, pp. 231-268 (2001)

（30）青木正喜:「ITS における画像認識の現状と課題」, 人工知能学誌, 15,2 , pp.234-241 (2000-2)

（31） 小沢慎治：「ITS における画像センシング技術の役割」，第 5 回画像セ ンシングシンポジウム, S-2, pp.367-372 (1999)

(32)「特集/これからのアクティブセーフティ: 各社の ASV 試作車」, 自 動車技術, 50, 11, pp.12-27 (1996-11)
(33) C.E.Thorpe, M.Hebert, S.A.Shafer, and T.Kanade : "Vision and Navigation for the Carnegie-Mellon NAVLAB”, IEEE Trans. PAMI, Vol.10, No.3, pp.361-372 (1988-3)

（34） 藤原秀人・関 真規人・熟見和彦・波部 斎:「テクスチャ背景差分と シルエットモデルを用いた車両追跡手法」, ワークショップ外観検査の 自動化 VIEW-2000, pp.79-84 (2000-12)

（35）川崎徹也・西山和人・徳留秀樹・阪本禎宏 :「画像処理を用いた交通量 計測設備の試行評価について」, 電学研資 RTA-99-29, pp.17-22 (1999)

（36）内丸年雄 - 小山泰一 - 小野寺浩 - 上田浩次 - 堀場勇夫 - 池谷和夫 : 「東 名高速道路足柄 SA(下り)における画像処理型駐車場案内システム」, 電学研資 RTA-91-14, pp.53-62 (1991)

（37）金山憲司・藤河義昌・藤本幸一：「実時間画像処理による車両番号認識 装置の開発と応用」, 信学論 D-II, J72D2, 10, pp.1663-1672 (1989-10)

（38）山田啓一・中野倫明・山本 新：「走行環境認識用広ダイナミックレン ジ視覚センサ」, 第 25 回画像工学コンファレンス論文集 10-4, pp.221-224 (1994)

(39) C. Stauffer and W.Grimson : "Adaptive Background Mixture Model for Real-time Tracking”, CVPR, pp.246-252 (1999)

(40) I.Haritaoglu, D.Harwood, and L.Davis : "W4: A Real-Time System for Detecting and Tracking People”, Face and Gesture, pp.222-227 (1998)

（41）関 真規人・和田俊和・藤原秀人・鷲見和彦：「背景の共起性に基づく 背景差分手法」, 情処 CVIM 研究会論誌 MIRU2002 特集号, 44, No.SIG5 (CVIM.6), pp.54-63 (2003-4)

（42）羽下哲司・藤原秀人・熟見和彦：「背景差分と動き心゙クトル解析を用い た屋外侵入監視システム」, SSII2002, A2, pp.7-12 (2002)

（43）羽下哲司・熟見和彦：「時間平均シルエットを用いた非剛体移動対象の 追跡」, SSII2003, D2 (2003)

（44） 今井 治：「最近のほんものの認証技術「総論」」, O plus E No.8, pp.853-865 (2002)

（45）星野幸夫：「指紋応用技術一指紋応用の歴史とシステムー」, 画像電子 学誌, 31,1 , pp.1-7 (2002-1)

（46）川嶋 操・木地和夫:「指紋と掌紋による個人識別技術」, 情報処理, 25, $6(1984-6)$

(47) 高木 晧 :「掌形(手のひら)の識別でセキュリティを守る」, エレクト ロニクス, 43, 2, pp.32-34 (1998-2)

（48）樋口正憲・田中敏幸:「位相限定相関法による手の静脈パターンを用い た個人認証」，2002 年信学会総合大会講演論文集，D-12-19 (2002)

（49）川崎雅也:「網膜の識別でセキュリティを守る」, エレクトロニクス, 43, 2, pp.52-54 (1998-2)

(50) J. D. Daugman : "Two-dimensional spectral analysis of cortical receptive field profiles", Vision Res. Vol.20, pp.847-856 (1980)

(51) A. Pentland and T. Choudhury : "Face recognition for smart environments", IEEE Conputer, pp.50-55 (February 2000)

（52）篠原克幸：「耳の識別でセキュリティを守る」，エレクトロニクス，43, 2, pp.41-43 (1998-2)

（53）佐藤雄隆・金子俊一・五十嵐悟：「周辺増分符号相関画像に基づくロバ スト物体検出及び分離」, 信学論, J84DII, 12, pp.2585-2594 (2001-12)

(54) R.T. Chin : "Survey: Automated Visual Inspection: 1981-1987", Computer Vision, Graphics, and Image Processing 41:346-381 (1988)

（55）高橋健太・三村昌弘・磯部義明・瀬戸洋一：「マルチモーダル生態認証 技術の現状と逐次確立比検定によるアプローチ」, 信学技報 BSG 1-4, pp.19-26 (2003)

（56）富永昌治:「カメラを用いた分光情報の計測と推定」, 色彩学誌, 24,1 , pp.24-28 (2000-1)

(57) W.Freeman, P.Beardsley, et al. : "Computer Vision for Computer Interaction, ACM SIGGRAPH newsletter", Vol.33, No.4 (1999), W.Freeman, and D.Anderson, et al. : "Computer Vision for interactive computer graphics", IEEE Computer Graphics and Applications, 18(3):42-53, May-June (1998)

(58) T.Horprasert, D.Harwood, and L.Davis : "A statistical approach for real-time robust background subtraction and shadow detection", ICCV' 99 Frame Rate Workshop, pp.1-19 (1999)

(59) R.J. Morris and D.C. Hogg : "Statistical Models of Object Interaction”, IJCV, Vol.37, No.2, pp.209-215 (2000-2)

（60）金子俊一：「実世界マシンビジョンのためのロバスト画像照合技術」, 電学論誌 (解説論文), 121-C, 5, pp.830-834 (2001-5)

(61) F. R. Hampel, E. M. Ronchetti, P. J. Rousseeuw and W. A. Stahel: "Robust Statistics", John Wiley \& Sons (1986) 
(62) S. Kaneko, I. Murase, and S. Igarashi : "Robust Image Registration by Increment Sign Correlation”, Pattern Recognition, Vol.35, No.10, pp.2223-2234 (2002-10)

（63） 三田雄志・金子敏充・堀 修：「微小な差異を含む画像の照合に適した 空間差分テンプレートの提案」, Proc. SSII, 9, pp.561-566 (2003)

(64) F. Ullah, S. Kaneko, and S. Igarashi : "Orientation Code Matching For Robust Object Search", IEICE Trans. on Inf. \& Syst., Vol.E84-D, No.8, pp.999-1006 (2001-8)

（65）古川賢司・岡田隆三・谷口恭弘・小野口一則：「車両用画像処理 LSI を用いた車両周辺監視システム」, Proc. SSII, 9, pp.227-232 (2003-9)

（66）島井博行・三島健稔・栗田多喜夫・梅山伸二:「移動物体検出のための ロバスト統計を用いた適応的な背景推定法」, Proc. MIRU, pp.391-396 (2000)

（67）坂田幸辰・金子俊一・高木裕治・奥田浩人：「テスト特徴法に基づく逐 次パタン学習と欠陷画像分類への応用」, 電学論誌 $\mathrm{C}$ (本特集号), C-124, 3, (2004-3)
熟 見 和 彦 (非会員) 1959 年 8 月 22 日生。 1984 年 3 月 京都大学大学院修士課程修了。工博。現在, 京 都大学大学院情報学研究科 COE 客員教授。コ ンピュータビジョンとパターン認識の研究に 従事。

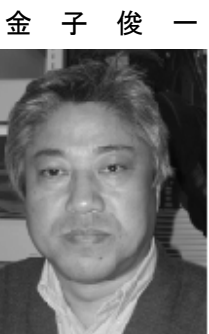

（正員） 1955 年 7 月 13 日生。 1980 年 3 月北 海道大学大学院修士課程修了。工博。現在, 北 海道大学大学院工学研究科助教授。画像応用計 測，ロバスト統計の画像センシングへの応用, 視覚応用制御などに研究に従事。 